\title{
Seismic Tomography of Garwhal-Kumaun Himalayas: Is the basal detachment a wistful thinking?
}

\section{S Mukhopadhyay ${ }^{1 *}$ J Sharma² and BR Arora ${ }^{2}$}

1 Department of Earth Sciences, IIT Roorkee, Roorkee-247667

2 Wadia Institute of Himalayan Geology, Dehradun

* For correspondence, email: sagarfes@iitr.ernet.in

We carried out seismic tomography in the Garhwal-Kumaun Himalayas using P- and S-phase data of local earthquakes. We observe that the near surface low velocity zones generally coincide with sedimentary formations, such as, inner and outer sedimentary formations and Berinag formations. The metamorphic rocks like Vaikrita, Almora and Ramgarh Groups show up as bodies having higher velocity. Many workers have suggested the presence of a gentle northerly dipping detachment that decouples Lower Himalaya sedimentary formations from underlying metamorphic crystalline basement. This suggestion is based in part on seismicity pattern. The present seismic tomographic work does not show a detachment surface but the interface is highly undulated. The nature of undulations varies strongly both across and parallel to the orogenic trend. Such strong undulations may indicate crustalscale folding and thrusting whose geometries vary across and along the trend of the Himalayas. As a consequence, the structural trend inferred from the velocity models, along cross sections that are $50 \mathrm{~km}$ apart vary significantly. The velocity sections suggest that the rock formations below the sedimentary cover-basement interface are also significantly deformed. This would mean that the deformation in this part is basement involved and not basement detached. 